\title{
Girl of Dreams Comes to Life
}

\author{
Zhengshun Han \\ Wuhan Textile University \\ Wuhan, China 430073
}

\begin{abstract}
Ruby Sparks is an American blockbuster that really sparks the imaginations of students and scholars alike worldwide. Since its release on July 25, 2012, it has garnered splendid praises, particularly, in terms of the archetypal/mythological criticism. As Maria Jernigan observes, "A mythological/ archetypal approach to literature assumes that there is collection of symbols, images, characters, and motifs (i.e. archetypes) that evokes basically the same response in all people. According to the psychologist Carl Jung, mankind possesses a 'collective conscious' that contain these archetypes and that is common to all of humanity. Myth critics identify these archetypal patterns and discuss how they function in the works." [1] So this thesis ventures to explore the plenty archetypes: character, symbols, and timeless archetypes expressive of Ruby Sparks.
\end{abstract}

Keywords-Pygmalion; Ruby archetypal/mythological; criticism; come to life

Sparks;

\section{INTRODUCTION}

Over its long history of China, there has always been a deeply-held but not openly publicized "feudalist notion" of Shū Zhōng Zì Yŏu Huáng Jīn Wū, Shū Zhōng Zì Yŏu Yán Rú Yù (Golden houses and beautiful wives can be found through study). Not long ago,a middle school teacher once utilized this as his banner cry to encourage his students, it functions pretty well but he was fired.Sad thing indeed! Coincidentally, I happened to watch this movie and suddenly hit upon the idea of the director's materializing this unique phenomenon in movie by the westerners. Possibility turns into a reality. How wonderful! I can't help exclaiming my enthusiasm and passion for this movie, as if it makes my dream come true, too.

In the West, the mythology of Pygmalion is a household word. It relates to a legendary figure of Cyprus named Pygmalion, a sculptor who carved a girl out of ivory and fell in love with it for after seeing the Propotides, he was "not interested in woman"[2].because his statue was so beautiful and so realistic. Over time, according to Ovid's narrative, when the festival day of Aphrodite came, Pygmalion made some offerings at Aphrodite's altar. Over there, too scared to admit his desire, he quietly made a wish for a bride who would be" the living likeness of my ivory girl" [3].Back home, he kissed his ivory statue, only to find that its lips felt warm. Then he kissed it again, finding that the ivory had lost its hardness. Thus, Aphrodite had granted Pygmalion's wish. This archetypal/mythological allusion can find its full expression in this movie of Ruby Sparks.

\section{THE CHARACTER ARCHETYPES EXPRESSIVE OF RUBY SPARKS}

The archetypal journey in this movie is Calvin's code breaking of the writing block after his high school dropout and become a successful boy wonder of his very first bestseller almost ten years ago. The archetypes are plenty. The movie contains character, symbolic and situational archetypes. These are utilized simply as shortcuts for the audiences so that viewers can better understand a character without having to know plenty things about it. Zoe Kazan, the writer, employs this piece of knowledge perfectly well by creating characters that a movie-goer can quickly connect with. Character Archetypes are ubiquitous. Beginning with the most conspicuous one, the hero of Calvin fills the role perfect well. "The hero is a protagonist whose life is a series of well-marked adventures". The biggest part of the hero is his quest for inspirations of writing a second best-seller. Then, Dr. Rosenthal suggests him to write about his uninspiring dog--- Scotty. Unlike most patients, Calvin took his suggestions very seriously and it worked wonder. Ruby, miraculously emerged when he types some words of saying his dog's going potty like a girl which makes him feel inadequate. Then he encounters Ruby who talks in exactly his style when he walks the dog on the pasture under a big trees. She proves to be a vulnerable woman who needs to be discovered by the hero. Though she left him in the end of the story, she did need him for the sake of her survival and companionship.

\section{THE SYMBOLIC ARCHETYPES EXPRESSIVE OF RUBY SPARKS}

Ruby Sparks revolves more around the plot line of having the archetypal "task" as contrasted to the "quest". The quest means more of a need to find something, whereas the task is more concentrated on doing/writing something. Calvin's key goal in life is, and the reason for his existence, is to get the inspiration of his girl of dreams. Generally speaking, in the very nature of the movie, the plot is supposed to follow the lines of a task. The symbolic archetypes in Ruby Sparks consist of "dream vs reality". The "confinement vs freedom" and "fuzzy vs clear". The dream / reality analogy is prevalent and conspicuous in this movie, however, the movie-goers must dig very deep to see the confinement vs freedom. Confinement means Calvin's taking complete command of Ruby simply by writing what he wishes her to be, while freedom refers to Ruby's absolute boredom and dull distaste of his solitary confinement without any friends or social activities, her strong wish to 
escape this state of affairs by taking art classes or going to parties for a nice change or experiment of staying alone. Also, fuzzy / clear have symbolic meanings. Here are the two that can be easily seen: fuzzy: shown by overall ambivalence of Ruby, backlit in the sunlight walks directly towards us head-on. "There you are. I've been looking for you. Where is my other shoe? Why are you looking at me like that?" It symbolizes chaos, mystery, the unknown etc. while clear means her long beautiful golden hair, light complexion, naiveté, light, and so on. "Fig. 1"

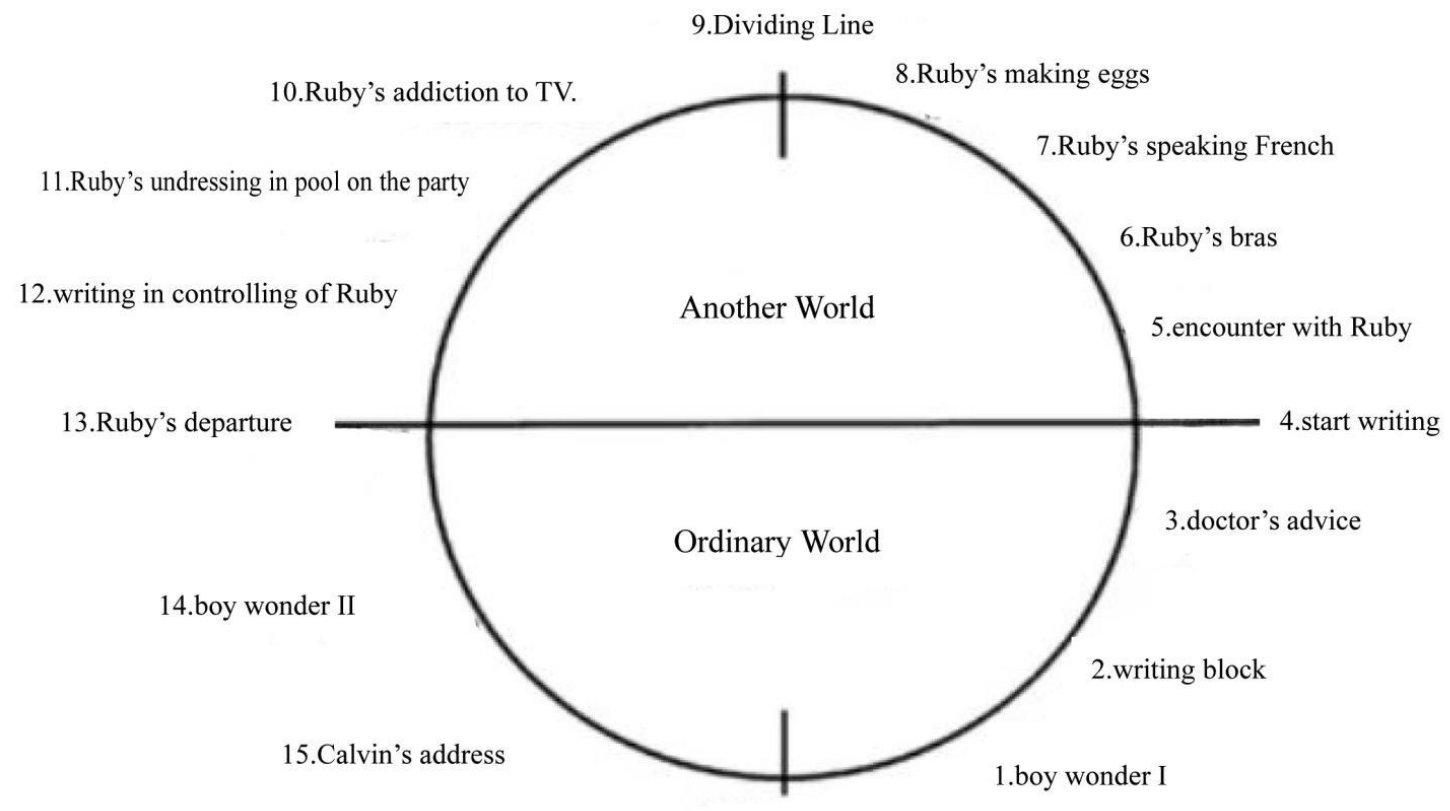

16.encounter with Ruby-like dream girl

Fig. 1. Miraculous Journey Map.

\section{The SituAtionAL ARCHETYPES EXPRESSIVE OF RUBY SPARKS}

In Jonathan Dayton's movie of Ruby Sparks, the story traces Calvin as the archetypal hero. It truly grasps the spirit of full miraculous journey. When the film starts, Calvin is cooped up in his house, wasting his precious life like a hermit. His trouble is that after his very first successful bestseller as a high school dropout, he simply can't figure out a second one. Then, in his dream, an ordinary girl just appears, though a little hazily and fuzzily. He is regarded by his father as having an "overactive imagination", so he consults Dr. Rosenthal who suggests him to write about his uninspiring dog---Scotty whose habit of going potty like a girl which makes Calvin feel quite inadequate. Miraculously, he simply starts to write. The next day, Ruby just shows up when Calvin was walking Scotty on the pasture under a big tree. She said exactly the same thing as what he writes about Scotty and said that she likes it as it is. Thus his wonderful journey starts, serving as his call to this extraordinary adventure. Thus, intrigued by Ruby, Calvin was brought out of his hermit-like lifestyle by her over the weekend.

Throughout this movie, Calvin's call for inspiration created many opportunities for a mentor figure to be present in his life. These mentors are primarily composed of two people: Doctor Rosenthal and Calvin's brother Harry. Doctor Rosenthal remains more of a mentor to Calvin by initiating this journey while Harry is a mentor that confirms Ruby's presence and forecasts her leaving for "Woman is a mysterious creature." from his own experience with Susie, Calvin's sister-in-law, and he has a deep, fatherly love for Calvin that resembles the love between God and Jesus while the love between Calvin and Ruby strongly suggests that between Pygmalion and his ivory sculpture--his girl of dreams.

The demarcation line of their romantic relationship is marked by the following threesome events when they get stuck together long for lack of variety and friends: (1) Ruby tends to be immersed in watching TV while Calvin asks her to attend a party which annoys him. (2) At the party, Calvin's unexpected encounter with Lila, his ex-girlfriend and also a writer, dig up their miserable past, which further annoys him. (3) Calvin's seeing of Ruby's undressing before the party-holder's invitation to swim in his pool makes him most annoying, whereas For Ruby, while crossing a road, Calvin was busy with answering a phone-call and letting go of her hand and leaving her on the other side, which makes her cry and hurts her enormously. So back home, Calvin lectures Ruby for her lack of propriety (being a slut in public), but she struggles for being unwilling to be decided by him. So, she leaves him as a sign of becoming totally free from his control. "As soon as Ruby left the house, the past released her. She was no longer Calvin's creation. She was free." [4] After that, he laments that "I couldn't see you 
when you were here. And now you have gone, I see you everywhere."

Now, in the end, the picture is changed to a park where Calvin walks his Scotty and encounters a Ruby-like girl reading his book:" Have we met before?" "I don't know." "You seemed so familiar. Maybe we have known each other in another world," She smiled." Please don't tell me the end, ok?" "I promise." Calvin said. With these marvelous remarks, we can well imagine Calvin's treasuring and treating Ruby as it is already made crystal clear by his lamenting words before in this world.

\section{CONCLUSION}

A special word deserves putting in for Scotty. Being Calvin's 24 hour companion, it acts as a live prop. Its archetype is nobody but Calvin himself: a male dog but goes poddy like a lady, so is Calvin, a man but considers himself as unsuitable for dating type, actually a sissy, to a certain extent. Most important of all, Ruby just likes this type of person as it is, without the slightest intention to change or modify him. Besides, it has its clone-Bobby-a Doll dog when Calvin consults Doctor Rosenthal in hospital. As the bridge between Calvin and Ruby, it appears at the outset, it appears in the middle (when they meet Calvin's parents, Scotty was put on a pair of glasses, "It is an intellectual." Calvin defends Scotty: "Don't make fun of Scotty!"), and it appears at the end. In other words, it is always together with us from start to finish, a timeless archetype that stands the test of time.

\section{REFERENCES}

[1] Breaking the code Wiki. http://breakingthecode.wiki.com/wiki.

[2] Morford,Mark(2007)."Classical Mythology". Oxford University Press, p.184.

[3] Pygmalion(mythology). https://en.wikipedia.org/wiki/Pygmalion(mythology).

[4] Yan Luo Lue Sha. Ruby Sparks. http://www.douban.com/note/254714713/ 